\title{
Herpetofauna diversity in the middle of the Southern Carpathians: data from a re- cent survey (2016-2018) in Cozia National Park (Romania)
}

\author{
Severus-Daniel Covaciu-Marcov, Paula-Vanda Popovici, Alfred-Ştefan Cicort-Lucaciu, István Sas-Kovács, \\ Diana Cupşa \& Sára Ferenţi
}

Keywords: amphibians, reptiles, habitats, altitude, forest type, mountains, differences, past

\section{Abstract}

Herpetofauna is of interest in protected areas because of the large number of protected species. We studied the herpetofauna of Cozia National Park (CNP) between 2016 and 2018. CNP is situated in the central part of the Southern Romanian Carpathians. We recorded 10 species of amphibian (Salamandra salamandra, Triturus cristatus, Lissotriton vulgaris, Bombina variegata, Hyla arborea, Bufo bufo, Bufotes viridis, Pelophylax ridibundus, Rana dalmatina and R. temporaria), and 11 reptile species (Lacerta agilis, L. viridis, Podarcis muralis, Darevskia praticola, Zootoca vivipara, Anguis colchica, Natrix natrix, N. tessellata, Coronella austriaca, Zamenis longissimus and Vipera ammodytes). Reptiles dominate in number of species, number of individuals and distribution records. CNP is situated at the northern limit of the distribution range of some of these reptiles, notably $D$. praticola and $V$. ammodytes. Mountain species associated with a colder, moist climate are very rare or even absent. Zootoca vivipara is restricted to the highest areas of Mount Cozia, above $1350 \mathrm{~m}$. Although mountain species are well represented in other Carpathian regions, the warmer, drier climate of CNP and its surroundings has limited their distribution in the area, pushing Z. vivipara to higher and higher altitudes. Lacerta agilis is syntopic with all the other lizard species. In some areas, as many as four lizard species cohabitate. The distribution of the herpetofauna in CNP has been negatively influenced by past human activity. The dams on the River Olt have favoured species related to large, stagnant bodies of water, in a region where such habitats were naturally missing. In addition, massive deforestation has decreased the abundance of herpetofauna in many areas of CNP.

\section{Profile}

Protected area

Cozia National Park

Mountain range

Carpathians

Country

Romania

\section{Introduction}

Protected regions at the periphery of the European Union are crucial for conserving species which are rare in the rest of the EU, although in some of these peripherally located countries, like Romania, species richness is still underestimated (see Hoffmann et al. 2018). In Romania, the network of protected areas is dense and compact (Rozylowicz et al. 2019). The total surface of these protected areas has recently been increased, but the management of the network as a whole is far from efficient (see Iojă et al. 2010; Niculae et al. 2017). Many of the country's protected areas, including Cozia National Park (CNP), are situated in the Carpathian Mountains, especially in the Southern Carpathians (Iojă et al. 2010). They also rank highest in the number of protected species (Rozylowicz et al. 2019).

CNP is remarkable for its landscapes and biodiversity (Ploaie 2004; Ploaie \& Turnock 2001), and its surroundings (Ploaie \& Turnock 1999). Some species of invertebrates (Covaciu-Marcov \& Ferenți 2019) and reptiles (Iftime \& Iftime 2006) in CNP extend to higher altitudes than in other areas of the country. Nevertheless, information on amphibians and reptiles in the Park does not cover the region fully or the species composition (Ploaie 2004; Ploaie \& Turnock 2001; Iftime \& Iftime 2006, 2007, 2017a). A recent publication (Iftime \& Iftime 2019), however, provides new distribution records of herpetofauna, as well as a literature review for the area. Herpetofauna is of high importance to conservation because almost all species in Romania are protected (O.U.G. 57/2007) and present in various protected areas (Iojă et al. 2010). In recent years, many studies have been conducted on herpetofauna both in protected regions (Ghira et al. 2012; Cicort-Lucaciu \& Muncuş-Nagy 2013; CovaciuMarcov et al. 2009a, 2014; Iftime \& Iftime 2014; Zamfirescu et al. 2016) and elsewhere (Dincă et al. 2013; Gaceu \& Josan 2013; Bogdan et al. 2014; Iftime \& Iftime 2015, 2017b). There have also been numerous studies on herpetofauna in protected areas of other countries (Tuberville et al. 2005; de Medeiros Magalhães et al. 2015; Kass et al. 2018; Leyte-Manrique et al. 2018). Any information on amphibian and reptile distribution is considered useful for conservation purposes (Iftime \& Iftime 2010; Hollanders et al. 2018; Leyte-Manrique et al. 2018).

In this context, we aimed to investigate the herpetofauna of CNP. Our objectives were: 1. to establish the distribution of the herpetofauna in CNP using 


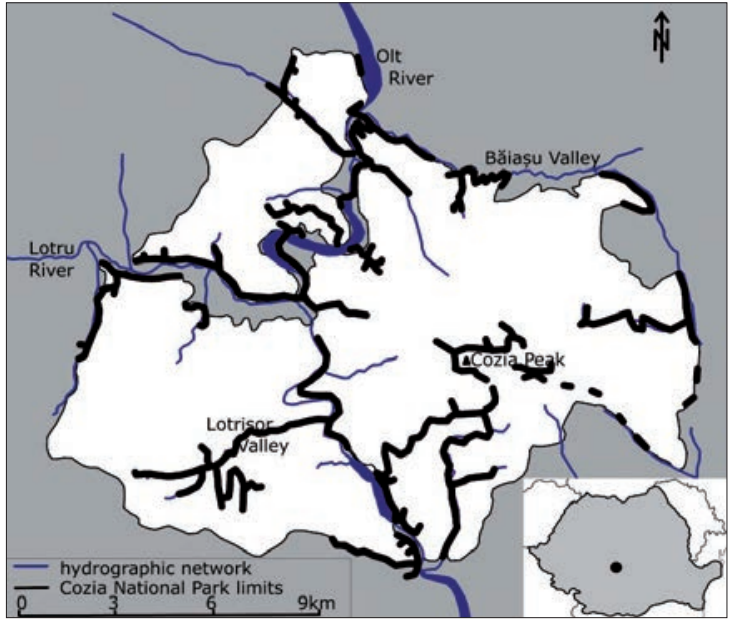

Figure 1 - The research paths taken in CNP (black thick lines - research paths; triangle - Cozia Peak).

distribution maps; 2. to identify the most important areas from an ecological and zoogeographical point of view; 3. to compare the herpetofauna of CNP with that of neighbouring areas.

\section{Material and Methods}

Field activities took place between 2016 and 2018, after Iftime \& Iftime had completed their own research in the area (see Iftime \& Iftime 2019). CNP lies in the central part of the Southern Carpathians, in the Olt River Gorge region. The gorge, situated at altitudes between $300 \mathrm{~m}$ and $400 \mathrm{~m}$, cuts through the Southern Carpathians (Tufescu 1986). CNP is situated at the gorge's southern end, having a peak with a maximum altitude of $1668 \mathrm{~m}$ (Ploaie 2004; Ploaie \& Turnock 2001). It was founded in 1990 and is the second oldest National Park in the country (Ploaie 2004). The Park has three distinct regions, each of which belongs to a different mountain massif, separated by the Olt and Lotru rivers (Ploaie 2004). CNP is mostly covered by forests, especially beech, but also oak, hornbeam and a few conifers (Ploaie 2004; Ploaie \& Turnock 2001). The Olt and its tributary the Lotru have been modified for hydro-electrical purposes (Rădoane \& Rădoane 2005; Cojocar 2014). The region is crossed by forest tracks and numerous tourist routes (Ovreiu et al. 2019) as well as by national roads.

We spent 25 days in the field in CNP. Field trips were usually made over the weekend, from April to September, each generally lasting 2-3 days. Because the herpetofauna species have very different ecological requirements (Fuhn 1960; Fuhn \& Vancea 1961), the chances of encountering them depended on the season and weather conditions. The best time for field work was spring, especially May. The herpetofauna inventory was made using direct methods, especially the transect method, various forms of which are recommended in studies of herpetofauna in Romania (see Török et al. 2013). These methods have been used in both Romania (Iftime \& Iftime 2006, 2007, 2019; Covaciu-Marcov et al. 2009b; Cicort-Lucaciu \& Muncuş-Nagy 2013; Bogdan et al. 2014) and other regions (Lamb et al. 1998, Tuberville et al. 2005; Kass et al. 2018; Ansari 2018; Leyte-Manrique et al. 2018; Slavchev et al. 2019). Animals were usually observed directly, without being captured or handled. A small number of amphibians were captured in some larger aquatic habitats using a net with a long metal handle, as used in similar studies (Covaciu-Marcov et al. 2009a, b; Ghira et al. 2012). They were released immediately after identification. As in other studies, road-killed animals were also identified (Tuberville et al. 2005; Strugariu et al. 2008; Covaciu-Marcov et al. 2009a, b, 2014).

We made dozens of transects (Figure 1) varying in length from several hundred metres to eight kilometres in one direction. Altogether, we walked more than $300 \mathrm{~km}$ in CNP. The Cozia Massif is generally accessible, but there are also areas whose accessibility is difficult or very difficult (Ovreiu et al. 2018). Thus, the region studied could not be covered uniformly. The transects generally overlapped with the region's access routes, such as forest tracks or tourist trails. In some cases, we deviated from the access routes and walked for a short distance into the forest. Because of some very inaccessible areas (Ovreiu et al. 2018), there were regions that we could not cross. Nevertheless, we explored large, characteristic areas of CNP, which is generally uniformly covered with forests (Ploaie 2004) over its entire altitudinal range. Thus, we consider that the transects are representative of the region. Transects were walked by 2 or 3 people at a time; one observed and identified the fauna, and the others made notes and took photos. Only a few transects were repeated. Because the transects were walked, they were travelled in both directions. The species distributions were marked on maps. For most species, a point on the map corresponds to one observed individual, although in some cases (notably for lizards) for which the number of observed individuals was too large, some distribution points overlap.

\section{Results}

Ten amphibian and 11 reptile species were identified in CNP. The amphibians were: Salamandra salamandra, Triturus cristatus, Lissotriton vulgaris, Bombina variegata, Hyla arborea, Bufo bufo, Bufotes viridis, Pelophylax ridibundus, Rana dalmatina and R. temporaria. The reptile species were: Lacerta agilis, L. viridis, Podarcis muralis, Darevskia praticola, Zootoca vivipara, Anguis colchica, $\mathrm{Na}$ trix natrix, N. tessellata, Coronella austriaca, Zamenis longissimus and Vipera ammodytes. These 21 species were recorded at 904 distribution points. Amphibians were observed at 361 points $(39.93 \%$ of the distribution records), and reptiles at 543 (60.06\% of the distribution records). The most-represented species in CNP was P. muralis, recorded at 157 points, followed by L. vir- 
Table 1 - Herpetofauna distribution points in CNP: percentage abundance of the distribution points, approximate altitudinal range, and distribution in habitat types: 1. natural forest, 2. recovery forest, 3. forest margin, 4. grassy areas (meadows, pastures), 5. mountain streams, 6. small wet areas (riverside coppices with alders, springs with small puddles in open areas), 7. large, artificial, wet areas, 8. rocky areas, 9. abandoned constructions, 10. buman settlements.

\begin{tabular}{|l|r|r|r|r|r|r|r|r|r|r|r|r|r|}
\hline Species & P [\%] & \multicolumn{1}{|c}{ Altitude } & 1. & 2. & 3. & 4 & 5. & 6. & 7. & 8. & 9. & 10. & Total \\
\hline Salamandra salamandra & 8.07 & $300-800$ & X & X & - & - & X & X & - & - & X & - & 5 \\
\hline Triturus cristatus & 0.44 & $350-750$ & $\mathrm{X}$ & - & - & X & - & X & X & - & - & - & 4 \\
\hline Lissotriton vulgaris & 0.55 & $350-1350$ & $\mathrm{X}$ & $\mathrm{X}$ & - & $\mathrm{X}$ & - & $\mathrm{X}$ & $\mathrm{X}$ & - & - & - & 5 \\
\hline Bombina variegata & 13.27 & $300-1200$ & $\mathrm{X}$ & $\mathrm{X}$ & $\mathrm{X}$ & $\mathrm{X}$ & $\mathrm{X}$ & $\mathrm{X}$ & - & - & $\mathrm{X}$ & $\mathrm{X}$ & 8 \\
\hline Bufo bufo & 5.86 & $300-1400$ & $\mathrm{X}$ & $\mathrm{X}$ & $\mathrm{X}$ & $\mathrm{X}$ & $\mathrm{X}$ & $\mathrm{X}$ & $\mathrm{X}$ & - & $\mathrm{X}$ & $\mathrm{X}$ & 9 \\
\hline Bufotes viridis & 0.22 & 350 & - & - & - & - & - & - & $\mathrm{X}$ & - & - & $\mathrm{X}$ & 2 \\
\hline Hyla arborea & 0.55 & 350 & $\mathrm{X}$ & - & - & - & - & - & $\mathrm{X}$ & - & - & - & 2 \\
\hline Rana dalmatina & 4.09 & $350-1200$ & $\mathrm{X}$ & $\mathrm{X}$ & $\mathrm{X}$ & $\mathrm{X}$ & $\mathrm{X}$ & $\mathrm{X}$ & $\mathrm{X}$ & - & $\mathrm{X}$ & $\mathrm{X}$ & 9 \\
\hline Rana temporaria & 2.65 & $350-1350$ & $\mathrm{X}$ & $\mathrm{X}$ & - & $\mathrm{X}$ & $\mathrm{X}$ & $\mathrm{X}$ & - & - & - & - & 5 \\
\hline Pelophylax ridibundus & 4.20 & $300-500$ & - & - & - & - & - & $\mathrm{X}$ & $\mathrm{X}$ & - & - & $\mathrm{X}$ & 3 \\
\hline Lacerata agilis & 7.96 & $350-1600$ & - & - & $\mathrm{X}$ & $\mathrm{X}$ & - & $\mathrm{X}$ & - & $\mathrm{X}$ & $\mathrm{X}$ & - & 5 \\
\hline Lacerata viridis & 14.82 & $300-700$ & - & - & $\mathrm{X}$ & $\mathrm{X}$ & - & - & - & $\mathrm{X}$ & $\mathrm{X}$ & $\mathrm{X}$ & 5 \\
\hline Podarcis muralis & 17.36 & $300-1000$ & - & - & $\mathrm{X}$ & - & - & - & - & $\mathrm{X}$ & $\mathrm{X}$ & $\mathrm{X}$ & 4 \\
\hline Darevskiy praticola & 2.54 & $350-850$ & $\mathrm{X}$ & - & $\mathrm{X}$ & - & $\mathrm{X}$ & $\mathrm{X}$ & - & $\mathrm{X}$ & - & - & 5 \\
\hline Zootoca vivipara & 2.21 & $1350-1650$ & - & - & $\mathrm{X}$ & $\mathrm{X}$ & - & $\mathrm{X}$ & - & - & - & - & 3 \\
\hline Anguis colchica & 5.19 & $300-1500$ & $\mathrm{X}$ & $\mathrm{X}$ & $\mathrm{X}$ & $\mathrm{X}$ & $\mathrm{X}$ & - & - & $\mathrm{X}$ & $\mathrm{X}$ & $\mathrm{X}$ & 8 \\
\hline Natrix natrix & 3.20 & $300-750$ & $\mathrm{X}$ & $\mathrm{X}$ & $\mathrm{X}$ & $\mathrm{X}$ & $\mathrm{X}$ & $\mathrm{X}$ & $\mathrm{X}$ & $\mathrm{X}$ & $\mathrm{X}$ & $\mathrm{X}$ & 10 \\
\hline Natrix tessellata & 3.31 & $300-400$ & - & - & - & - & - & $\mathrm{X}$ & $\mathrm{X}$ & - & - & $\mathrm{X}$ & 3 \\
\hline Coronella austriaca & 0.44 & $300-400$ & - & - & $\mathrm{X}$ & - & - & - & - & - & - & - & 1 \\
\hline Zamenis longissimus & 2.54 & $300-500$ & $\mathrm{X}$ & - & $\mathrm{X}$ & $\mathrm{X}$ & - & $\mathrm{X}$ & - & $\mathrm{X}$ & - & $\mathrm{X}$ & 6 \\
\hline Vipera ammodytes & 0.44 & $350-650$ & $\mathrm{X}$ & - & $\mathrm{X}$ & - & - & - & - & $\mathrm{X}$ & - & - & 3 \\
\hline Total & & & 13 & 8 & 13 & 12 & 8 & 14 & 9 & 8 & 9 & 11 & - \\
\hline
\end{tabular}

idis, registered in 134 points. Among the amphibians, B. variegata was the most common species, present at 120 distribution points. The rarest herpetofauna species were $B$. viridis, present at only two points, followed by $T$. cristatus, $C$. austriaca and $V$. ammodytes, each recorded at four points (Figures 2-5).

Herpetofauna species are unevenly distributed in CNP (see Figures 2-5). Some are present virtually throughout $\mathrm{CNP}$, like $B$. variegata, $\mathrm{R}$ dalmatina or $A$. colchica. Others (D. praticola and Z. vivipara) are present only in the Cozia Massif area, while yet others are present only in wet areas at low altitudes along the Olt, Lotru and Băiaşu rivers ( $P$. ridibundus, $H$. arborea, or N. tessellata). Only one species, N. natrix, was recorded in all the habitat types of CNP, while Coronella austriaca was recorded in just one habitat type, in forest margins (Table 1). The largest number of species was registered in small-sized wet areas, followed by natural forests and forest margins. Except for Z. vivipara, all species were present in the low altitude areas of CNP (Table 1), each ascending to different altitudes. Lacerta agilis has the widest altitude distribution in the Park (Table 1).

\section{Discussion}

In most Romanian regions, amphibian species are more numerous than reptile species (Strugariu et al. 2008; Ghira et al. 2012; Dincă et al. 2013; Cicort-Lucaciu \& Muncuş-Nagy 2013; Bogdan et al. 2014; Covaciu-Marcov et al. 2014; Iftime \& Iftime 2011, 2013, 2014, 2017b). CNP is exceptional in having more reptile than amphibian species; there are few other such regions in southern Romania (Krecsák et al. 2004; Covaciu-Marcov et al. 2006, 2009a, b; Iftime \& Iftime 2008). The number of reptile distribution records is an underestimate, because in the case of lizards occasionally more than one individual was observed per point. Also, in CNP there is a predominance of species which prefer a warmer climate.

Two reptiles, $D$. praticola and $V$. ammodytes, are eastMediterranean species (Tomović et al. 2014), so Romania is at their northern distribution limit (Sillero et al. 2014). Darevskia praticola was not mentioned in the region in the most recent review on reptile distribution in Romania (Cogălniceanu et al. 2013a). Nevertheless, it has been registered in CNP since 2007, where although rare it seems to be present at the highest altitude in the country (Iftime \& Iftime 2006). Darevskia praticola is well represented in $\mathrm{CNP}$, even if the region lies at the limit of its suitability area (Ćorović et al. 2018). Although it was previously recorded at higher altitudes (Iftime \& Iftime 2006), we identified D. praticola only below $850 \mathrm{~m}$, near Stânişoara Monastery, alongside the Carpathian scorpion (Covaciu-Marcov \& Ferenți 2019), another species related to a sub-Mediterranean climate (Bunescu 1959).

Darevskia praticola is unevenly distributed in CNP, as previously reported (Iftime \& Iftime 2019). It is present only east of the River Olt, on the western side of the Cozia Massif; it was not encountered to the east of the Cozia Massif, either because of the colder climate (Stoenescu et al. 1966) or because of high forest disturbance. This area was heavily deforested in the past (Ploaie 2004; Ploaie \& Turnock 2001); the construc- 

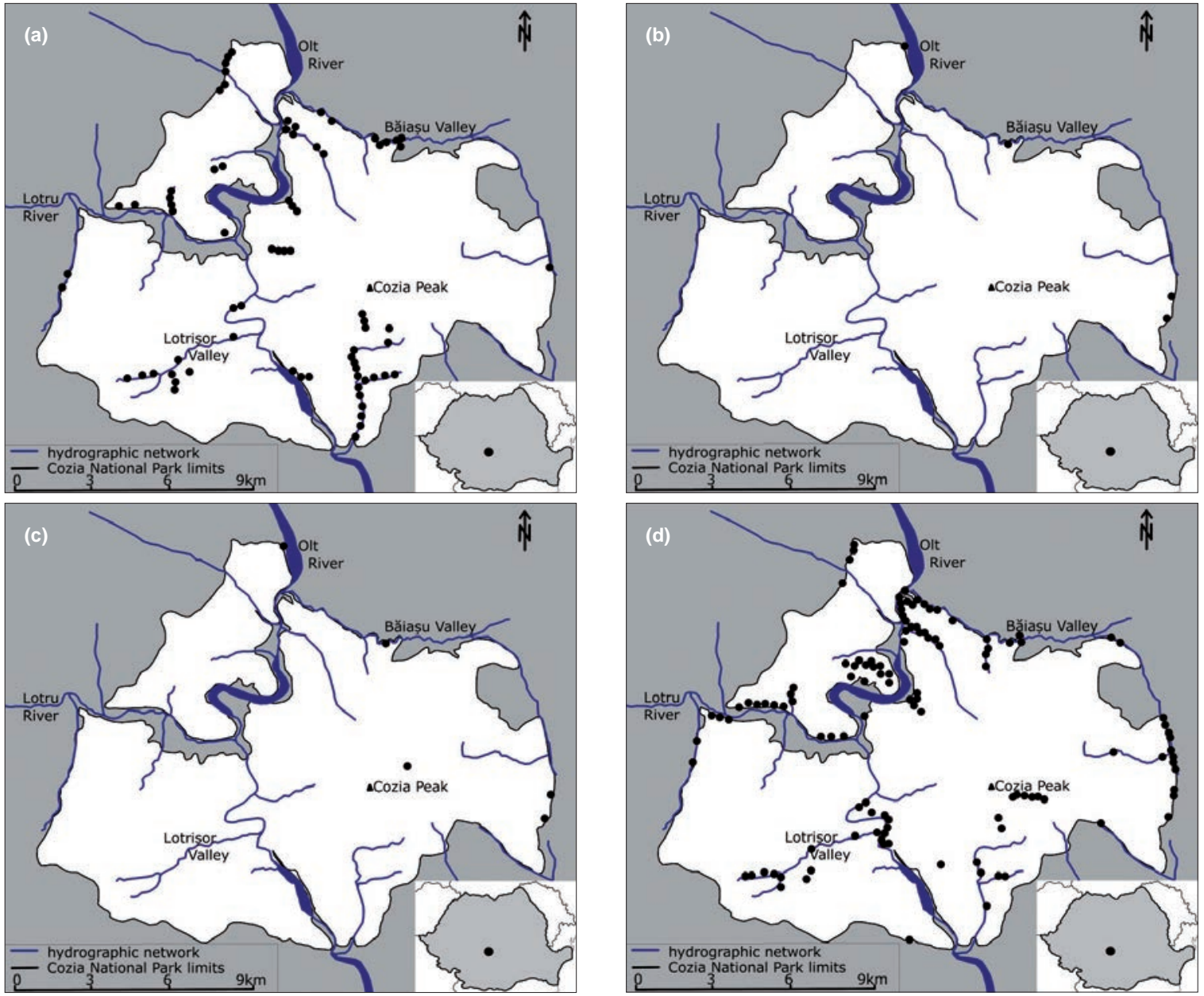

Figure 2 - The distribution (black dots) in CNP of (a) S. salamandra, (b) T. cristatus, (c) L. vulgaris and (d) B. variegata.

tion of a narrow-gauge forest railway served to increase the deforestation by giving access to more areas (Turnock 2005). According to local people, large areas were completely cleared of trees. Today, the eastern CNP is covered by coniferous plantations and dense beech and hornbeam regeneration forests.

The populations of Darevskia praticola in CNP seem to be isolated, both from the western ones in the Jiu River Gorge (Covaciu-Marcov et al. 2009a, Sucea 2019) and from the eastern ones in the Curvature Carpathians (Gherghel et al. 2011). This fragmentation is apparent also from the species' absence from the areas surrounding CNP, where it has not been attested (Iftime \& Iftime 2011, 2013, 2014; Covaciu-Marcov et al. 2014; Dincă et al. 2013). While the isolation can be explained by deforestation in some areas (Gherghel et al 2011), this forest species has access to continuous habitats in the lower Southern Carpathians, and climatic models also show suitable areas (Ćorović et al. 2018). The Carpathian scorpion has a similar distribution; populations in the Olt River Gorge seem to be isolated from the ones in the Jiu Gorge and the Curvature Carpathians (Bunescu 1959; Gherghel et al. 2016). Although with fewer distribution records, $V$. ammodytes is present in the same areas of CNP as D. praticola. The western part of the Cozia Massif is the eastern distribution limit of this species in the Romanian Carpathians (Cogălniceanu et al. 2013a).

CNP is remarkable also because of the scarcity or absence of some mountain species. This is the case of Mesotriton alpestris and Vipera berus, which have not been recorded in CNP, and Z. vivipara, which has a very rare and localized distribution. The absence of the first two species distinguishes the herpetofauna of CNP as a whole from that of the Jiu River Gorge (CovaciuMarcov et al. 2009a). In the Jiu Gorge, these species are also rare and present only above $1200 \mathrm{~m}$ (CovaciuMarcov et al. 2009a). Both were intensely searched for in the Cozia Massif, to no avail. Even at an altitude of $1350 \mathrm{~m}$, where Z. vivipara is already present, we identified only $L$. vulgaris, although we expected to find $M$. alpestris, which is commonly present above $800 \mathrm{~m}$ in the eastern proximity of CNP, in the Topolog (Dincă et al. 2013) and Vâlsan river basins (Covaciu-Marcov et al. 2014). Vipera berus is also present at higher altitudes some dozens of $\mathrm{km}$ from CNP (Krecsák et al. 2004; Iftime 2005; Iftime \& Iftime 2010; Dincă et al. 2013). It is possible that the presence of the species in the Jiu Gorge is favoured by the proximity of the Parâng Massif, which reaches altitudes of over $2500 \mathrm{~m}$, and has a colder and more humid climate (Stoenescu et al. 1966). Massifs reaching more than $2500 \mathrm{~m}$ are further 

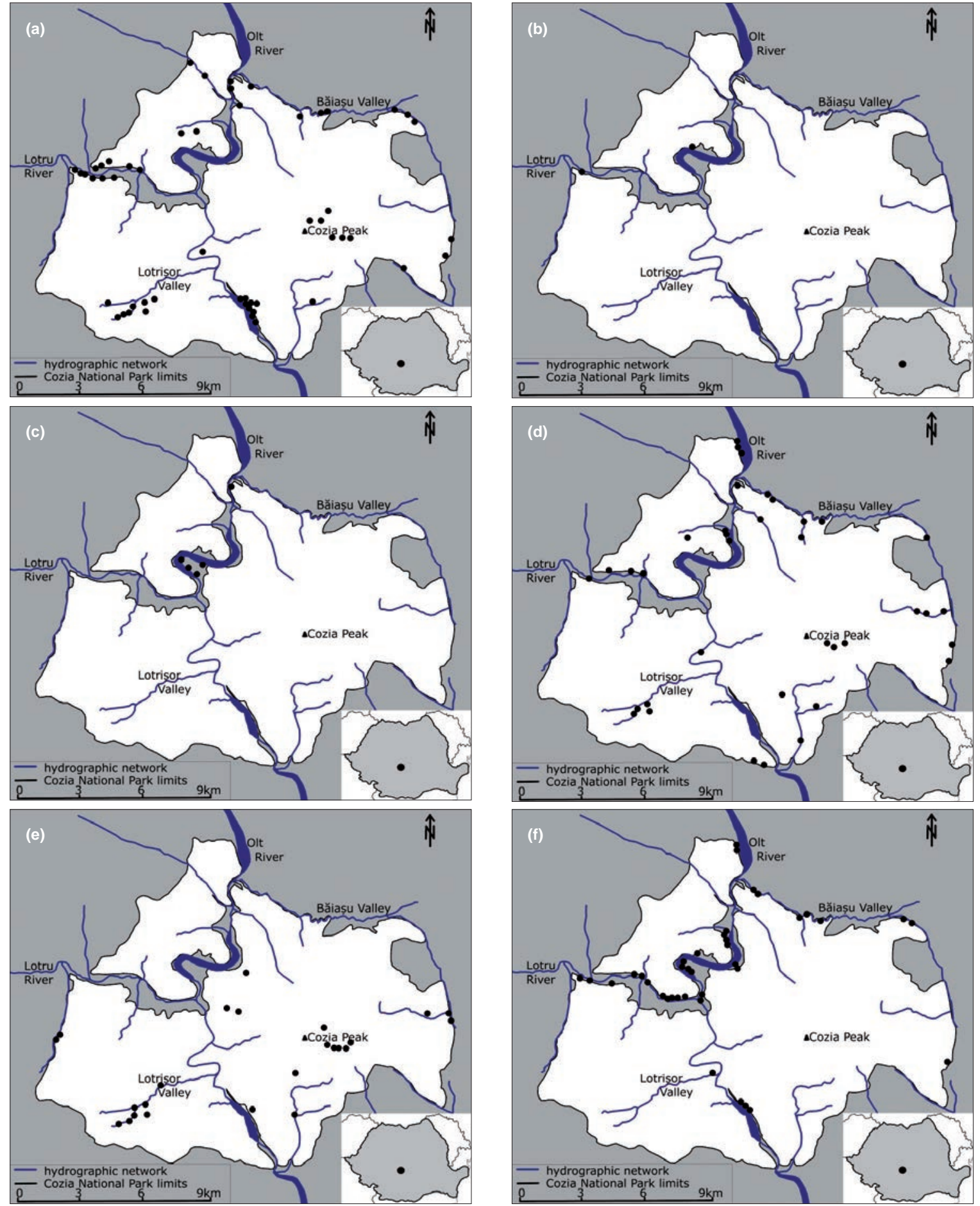

Figure 3 - The distribution (black dots) in CNP of (a) B. bufo, (b) B. viridis, (c) H. arborea, (d) R. dalmatina, (e) R. temporaria and (f) P. ridibundus

from CNP, and because of this CNP has a warmer, drier climate (Stoenescu et al. 1966).

Zootoca vivipara is present only in the highest areas of the Cozia Massif, where it was recently mentioned (Iftime \& Iftime 2019); we found it above $1350 \mathrm{~m}$. This is among the highest lower-altitudinal limits for the species in Romania; in other regions it is present from 800 m upwards (Iftime \& Iftime 2013) and has even been recorded in plains (Covaciu-Marcov et al. 2008). To the west, in the Jiu River Gorge, its presence starts at $1200 \mathrm{~m}$ (Covaciu-Marcov et al. 2009a); in the Jieț Gorge, it is found above $1100 \mathrm{~m}$ (Iftime \& Iftime 2010); to the east, in the Vâlsan river basin, it descends to $800 \mathrm{~m}$ (Covaciu-Marcov et al. 2014). Zootoca vivipara seems completely isolated in the highest part of the Cozia Massif, over an area of just a few $\mathrm{km}^{2}$. The Cozia Massif is delimited to the east and north by the Olt and Băiaş rivers. It is connected to other mountain areas only to the east through a peak of about $750 \mathrm{~m}$, which is below this species' lowest altitudinal 

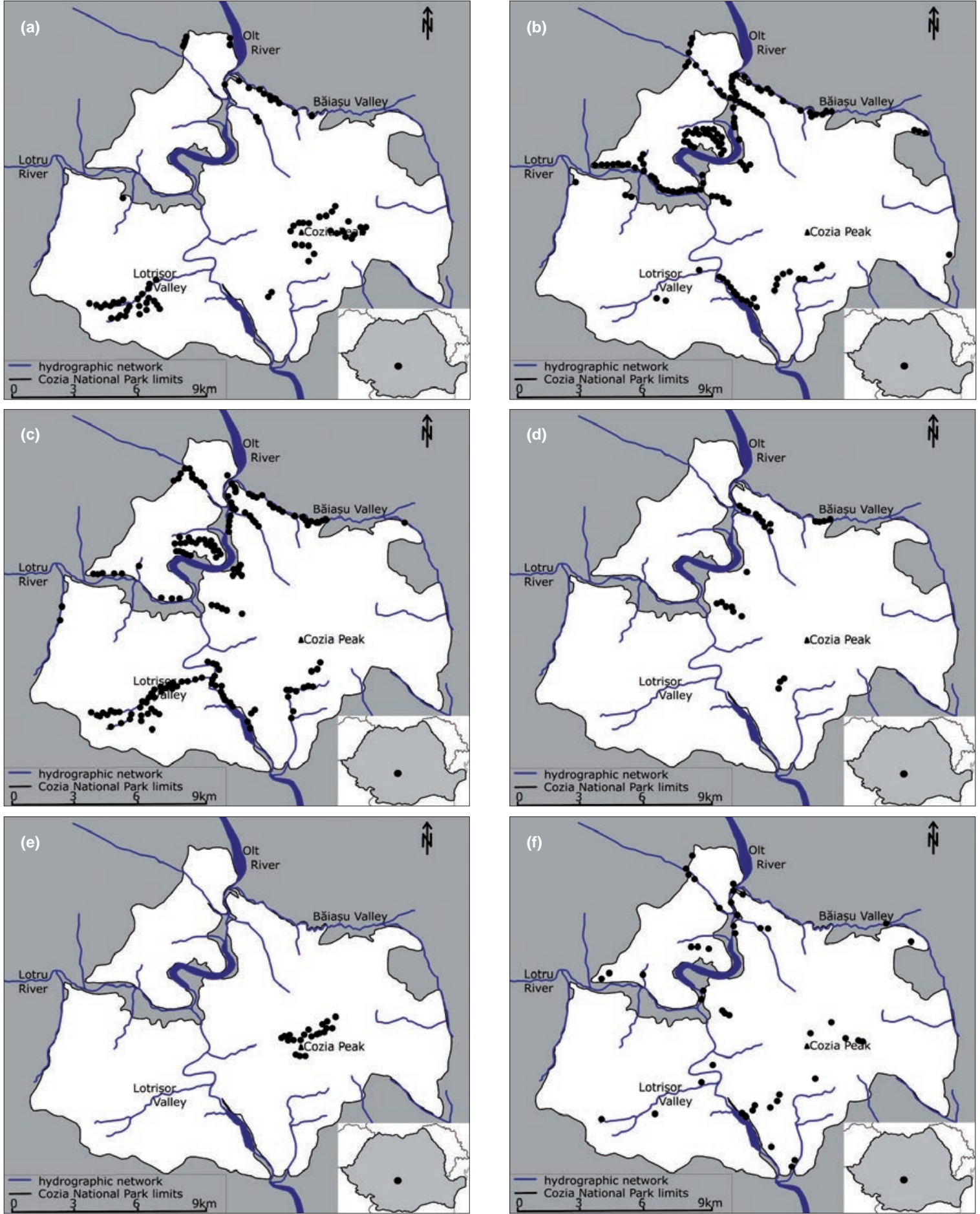

Figure 4 - The distribution (black dots) in CNP of (a) L. agilis, (b) L. viridis, (c) P. muralis, (d) D. praticola, (e) Z. vivipara and $(f)$ A. colchica.

limit in the area. Zootoca vivipara habitats in CNP are similar to those of other populations, such as mountain meadows, and the margins of coniferous forests (Iftime 2005; Covaciu-Marcov et al. 2009a). Even at $1600 \mathrm{~m}, Z$. vivipara is present alongside $L$. agilis. The high temperatures around the Cozia Massif (Stoenescu et al. 1966) pushed Z. vivipara populations to higher altitudes, isolating them from the ones in the southern Făgăraş Mountains; thus, they are relicts of a former distribution in the area. Any future climate change could cause their disappearance because they would not find any higher suitable habitats this close to the mountain peak. Zootoca vivipara from the Cozia Massif probably belongs to the haplogroup recently described in the Făgăraş Mountains (Velekei et al. 2015), which increases its conservation value. Due to its presence at high altitudes, Z. vivipara coexists only with $L$. agilis, although near CNP, in the Vâlsan river basin, it is present alongside P. muralis (Covaciu-Marcov et al. 2014). Lacerta agilis can coexist with all the other lizard spe- 

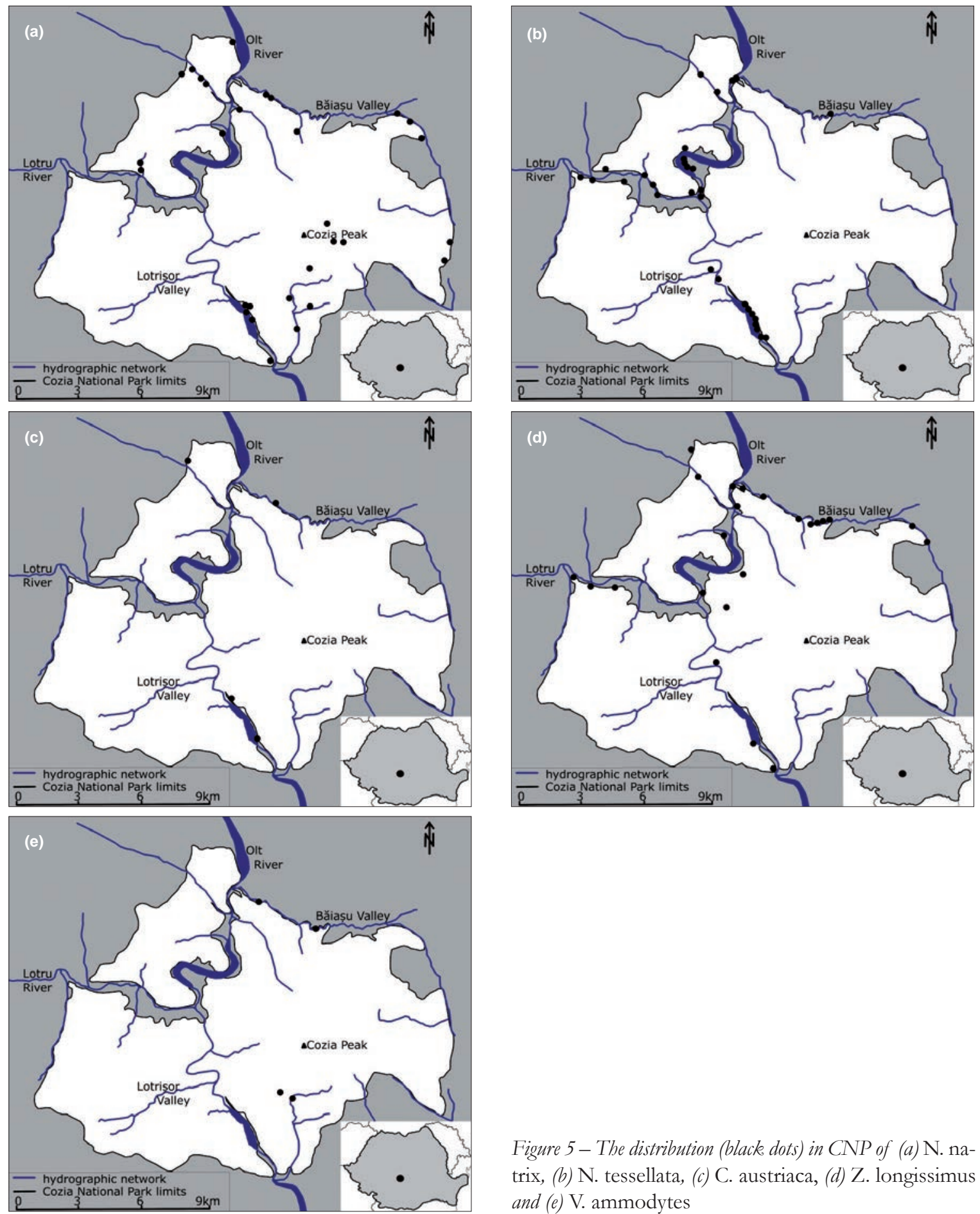

Figure 5 - The distribution (black dots) in CNP of (a) N. natrix, (b) N. tessellata, (c) C. austriaca, (d) Z. longissimus and (e) V. ammodytes

cies. In the highest areas of the Cozia Massif, L. agilis is syntopic with Z. vivipara. It is the only lizard present between $1000 \mathrm{~m}$ and $1350 \mathrm{~m}$. Below this altitude, it co-occurs with $L$. viridis, $P$. muralis or $D$. praticola. These four lizard species (L. agilis, L. viridis, P. muralis and D. praticola) are rarely syntopic (Lotrişoru de Cozia valley). In CNP, P. muralis ascends to almost $1000 \mathrm{~m}$ along forest roads and sunny slopes.

CNP's herpetofauna is dominated by forest and rock-loving species, which is to be expected since forests occupy most of the park (Ploaie 2004; Ploaie \& Turnock 2001). The rarest amphibian is B. viridis, which was recorded at only two points, inside and near human settlements. Despite having been mentioned upstream of CNP (Fuhn 1960; Krecsák et al. 2004), B. viridis probably benefits from human settlements in the area because it is a steppe species (Fuhn 1960) with few natural habitats in the Park. It was recently reidentified in the region, but also in or near human settlements (Iftime \& Iftime 2019). Coronella austriaca and $V$. ammodytes are the rarest reptiles. C. austriaca is a difficult species to observe (Hartel et al. 2009). $V$. ammodytes is at the limit of its distribution range and requires particularly rare habitats and conditions 
(Ghira 2016). The presence of both species in the area has been noted in various publications (see a review in Iftime \& Iftime 2019). Some rarely mentioned species, such as $V$. ammodytes (see in Iftime \& Iftime 2019), were recorded by us at more distribution points.

Because increasing sampling effort leads to evidence of greater species richness (Băncilă et al. 2014), new field studies could lead to new distribution records of the known species or even of species that we did not encounter. It is also possible that some species were not accurately represented in our maps, as we may have missed their peak activity due to differences in species ecology (Fuhn 1960, Fuhn \& Vancea 1961) and weather conditions. Furthermore, not all regions of CNP were covered in the same amount of detail: Mount Narăț, for example, was less well covered. In 2018, the region was affected by strong winds that toppled trees and rendered some tourist routes inaccessible. Despite these methodological shortcomings, it can be seen that the herpetofauna of CNP is richer than that of many areas in the Southern Carpathians (Iftime 2005; Iftime \& Iftime 2010, 2013, 2014; Covaciu-Marcov et al. 2014; Dincă et al. 2013), but poorer than in some hotspots, like the Jiu River Gorge (Covaciu-Marcov et al. 2009a): most mountain species associated with colder climate are absent from CNP, which is an oasis for warmer-climate species. Nevertheless, there are similarities between the herpetofauna of CNP and that of other regions in the Southern Carpathians. Newts are rare in CNP, as they are in the Jiu River Gorge, Danube Gorge and Jieț valley (Covaciu-Marcov et al. 2009a, b; Iftime \& Iftime 2010), where the steep slopes provide very few suitable breeding habitats (Covaciu-Marcov et al. 2009a, b; Iftime \& Iftime 2010). Newts in CNP are present either in partially artificial wet areas near the river Olt, or in ponds formed as a result of landslides in the eastern CNP. Only L. vulgaris is present in small ponds in the peak area of the Cozia Massif.

Earlier human activities, such as the hydro-electrical works and heavy deforestation, have had an impact on the herpetofauna of CNP. Nowadays, the Olt is a succession of dams, in both the gorge and downstream sections (Rădoane \& Rădoane 2005). Its tributary, the Lotru, has suffered the most modifications of this type in the country (Cojocar 2014). P. ridibundus and Natrix tessellata are probably favoured by the dams, which form stagnant bodies of water in an area naturally devoid of such habitats. Because of the lack of historical data, we cannot know how much has been lost due to the dams. The dams are also the reason why the railway was moved; thus, new tunnels were made, and some old ones were abandoned (Turnock 2006; Bellu 2010). Two abandoned tunnels were flooded, but one is above the water level and is used by some amphibians. More than $50 \mathrm{~m}$ inside this particular tunnel, we identified B. variegata individuals, and even one B. bufo. Bombina variegata was recently recorded in caves (Russo et al. 2018) and had already been sighted in abandoned tunnels (Covaciu-Marcov et al. 2017a). This confirms that abandoned railroad tunnels may be used by amphibians even in natural areas (Covaciu-Marcov et al. 2017a).

Other structures left behind by human activity, however, have negative effects on herpetofauna, like the vertical pipes open at ground level in which some amphibians get trapped. Massive deforestation has shaped the appearance of today's forests in CNP, and in the Southern Carpathian region, between the Olt and the Jiu, there were many sawmills (Turnock 2006). The effects of this activity are still apparent: many forests, especially in the eastern CNP, are regenerated forests or plantations. Herpetofauna is poorer in these areas, and similar cases have already been recorded (Covaciu-Marcov et al. 2009a). Deforestation continues, but on a smaller scale and in the already affected regions.

Nowadays, human impact in CNP is reduced and at a constant level. However, it could increase in the future because of plans for a highway to pass through its northern area, in the Băiaşu valley (Anonymous 2018). Băiaşu Gorge is an area with a rich herpetofauna, which should be taken into consideration when constructing the highway. As in other regions of Romania (Ciolan et al. 2017; Covaciu-Marcov et al. 2017b), road traffic already has a negative impact on the herpetofauna of CNP, as numerous individuals are killed, even on roads with little traffic. The richest herpetofauna in CNP is to be found in the southern and western parts of the Cozia Massif, in its higher area, and in the Băiaşu, Lotrişor, Călineşti and Bețel valleys. These areas should be kept free of human interventions, especially in the natural primary forests, where deforestation should be prohibited (see Schrödl 2019). The eastern areas could be included in restoration programmes, replacing coniferous plantations with native forests. As long as the human impact is maintained within its current limits, the future of CNP's herpetofauna seems secure.

\section{Acknowledgments}

This study was carried out in collaboration with the Cozia National Park Administration. We would like to thank to Diana L. Delibaltov (Google, Mountain View, CA, USA) for revising the language of the manuscript.

\section{References}

Anonymous 2018. Acord de Mediu pentru proiectul Autostrada Sibiu - Piteşti. ANPM Bucureşti. [In Romanian].

Ansari, N.A. 2018. Enumeration of Herpetofaunal assemblage of Surajpur Wetland, National Capital Region (India). Amphibian \& Reptile Conservation 12(2): 90-97.

Băncilă, R.I., D. Cogălniceanu, R. Plăiaşu, M. Tudor, C. Cazacu \& T. Hartel 2014. Comparative per- 
formance of incidence-based estimators of species richness in temperate zone herpetofauna inventories. Ecological Indicators 45: 219-226.

Bellu, R. 2010. Romania, mica monografie a tunelurilor de cale ferata (1856-2009). Tipografia Filaret S.A., Bucureşti. [In Romanian].

Bogdan, H.V., I. Sas-Kovács \& S.D. Covaciu-Marcov 2014. Herpetofaunistic diversity in Lipova Hills, western Romania: Actual and past causes. Biharean Biologist 8(1): 48-52.

Bunescu, A. 1959. Contribuții la studiul răspândirii geografice a unor animale mediterannene din R.P.R. Nota I. Artropode. Probleme de Geografie 6: 87-107. [In Romanian].

Cicort-Lucaciu, A.Ş. \& K. Muncuş-Nagy 2013. Some data about the herpetofauna of two natural protected areas from Transylvania, Romania and their surroundings. Herpetologica Romanica 7: 1-21.

Ciolan, E., A-Ş. Cicort-Lucaciu, I. Sas-Kovács, S. Ferenți \& S.-D. Covaciu-Marcov 2017. Wooded area, forest road-killed animals: Intensity and seasonal differences of road mortality on a small, newly upgraded road in western Romania. Transportation Research Part D: Transport and Environment 55: 12-20.

Cogălniceanu, D., L. Rozylowicz, P. Székely, C. Samoilă, F. Stănescu, M. Tudor, D. Székely \& R. Iosif 2013a. Diversity and distribution of reptiles in Romania. ZooKeys 341: 49-76.

Cogălniceanu, D., P. Székely, C. Samoilă, R. Iosif, M. Tudor, R. Plăiaşu, F. Stănescu \& L. Rozylowicz 2013b. Diversity and distribution of amphibians in Romania. ZooKeys 296: 35-57.

Cojocar, M. 2014. Representative dams in Romania. Hidrotehnica 59(12): 3-23.

Covaciu-Marcov, S.-D. \& S. Ferenți 2019. An endemic species in a protected area: Euscorpius carpathicus (L., 1767) in the Cozia National Park, Romania (Scorpiones: Euscorpiidae). Euscorpius 279: 1-6.

Covaciu-Marcov, S.-D., I. Ghira, A.-Ş. Cicort-Lucaciu, I. Sas, A. Strugariu \& H.V. Bogdan 2006. Contributions to knowledge regarding the geographical distribution of the herpetofauna of Dobrudja, Romania. North-Western Journal of Zoology 2(2): 88-125.

Covaciu-Marcov, S.-D., A.-Ş. Cicort-Lucaciu, S. Ferenți \& A. David 2008. The distribution of lowland Zootoca vivipara populations in North-Western Romania. North-Western Journal of Zoology 4(1): 72-78.

Covaciu-Marcov, S.-D., A.-Ş. Cicort-Lucaciu, F. Dobre, S. Ferenți, M. Birceanu, R. Mihuț \& A. Strugariu 2009a. The herpetofauna of the Jiului Gorge National Park, Romania. North-Western Journal of Zoology 5 (Supplement 1): S1-S78.

Covaciu-Marcov, S.-D., A.-S. Cicort-Lucaciu, O. Gaceu, I. Sas, S. Ferenți \& H. V. Bogdan 2009b. The herpetofauna of the south-western part of Mehedinți County, Romania. North-Western Journal of Zoology 5(1): 142-164.

Covaciu-Marcov, S.-D., A.-Ş. Cicort-Lucaciu, I.C. Telcean, A. Pal \& I. Sas-Kovács 2014. Some notes on the herpetofauna from Vâlsan River natural protected area, Romania. Carpathian Journal of Earth and Environmental Sciences 9(3): 171-176.

Covaciu-Marcov, S.-D., S. Ferenți, I. Urák, É.-H. Sas-Kovács, A.-Ş. Cicort-Lucaciu \& I. Sas-Kovács 2017a. After the last train passes: data on the fauna from abandoned railway tunnels in Romania. Annales Zoologici Fennici 54: 335-346.

Covaciu-Marcov, S.-D., A. Puskás, A.N. Pop, M. Țârț \& S. Ferenți 2017b. Road-killed Amphibian and Reptiles on a Local Road in a Protected Area in Western Romania. Acta Zoologica Bulgarica 69(1): 115-120.

Ćorović, J., M. Popović, D. Cogălniceanu, M.A. Carretero \& J. Crnobrnja-Isailović 2018. Distribution of the meadow lizard in Europe and its realized ecological niche model. Journal of Natural History 52(2930): 1909-1925.

de Medeiros Magalhães, F., D.O. Laranjeiras, T.B. Costa, F.A. Juncá, D.O. Mesquita, D.L. Röhr, W.P. da Silva, G.H.C. Vieira \& A.A. Garda 2015. Herpetofauna of protected areas in the Caatinga IV: Chapada Diamantina National Park, Bahia, Brazil. Herpetology Notes 8: 243-261.

Dincă, P.C., A. Strugariu, A. Iftime, O. Iftime, O. Zamfirescu \& Z. Zamfirescu 2013. Herpetofauna from the upper Topolog River basin (Romania). Analele Ştiințifice ale Universitățtii ,Alexandru Ioan Cura” din Iaşi, s. Biologie animală 59: 61-68.

Fuhn, I. 1960. "Fauna R.P.R.”, vol. XIV, Fascicola I, Amphibia. Editura Academiei R.P.R., Bucharest. [In Romanian].

Fuhn, I. \& Ş. Vancea 1961. "Fauna R.P.R.”, vol. XIV, Fascicola II, Reptilia. Editura Academiei R. P. R., Bucharest. [In Romanian].

Gaceu, O. \& I. Josan 2013. Note on the occurrence of Darevskia pontica (Reptilia) north of Mureş River, in Metaliferi Mountains, western Romania. North-Western Journal of Zoology 9(2): 450-452.

Gherghel, I., A. Strugariu, T. Sahlean \& A. Stefanescu 2011. New Romanian distribution record for Darevskia praticola pontica (Lantz and Cyrén, 1919) at its north-western range limit. Herpetozoa 23(3/4): 91-93.

Gherghel, I., A. Sotek, M. Papeş, A. Strugariu \& L. Fusu 2016. Ecology and biogeography of the endemic scorpion Euscorpius carpathicus (Scorpiones: Euscorpiidae): a multiscale analysis. Journal of Arachnology 44: 88-91.

Ghira, I. 2016. Ecologia, etologia, si distributia geografică a viperei cu corn (Vipera ammodytes ammodytes L., 1758) în România. Presa Universitară Clujeană, Cluj-Napoca. [In Romanian].

Ghira, I., S.-D. Covaciu-Marcov, A.-Ş. Cicort-Lucaciu \& I. Sas 2012. Notes upon the herpetofauna of the Cefa Nature Park, (Crişana, Romania). Transylvanian Review of Systematical and Ecological Research 13: 171-176.

Hartel, T., K. Öllerer, L. Farczády, C.I. Moga \& R. Băncilă 2009. Using species detectability to infer distribution, habitat use and absence of a cryptic species: 
the smooth snake (Coronella austriaca) in Saxon Transylvania. Biologia Acta Scientiarum Transylvanica 17(1): 61-76.

Hollanders, M., F. Serrano, T. Leerschool \& W. Beukema 2018. New and recent herpetological records from Soria, Spain. Boletín de la Asociación Herpetológica Española 29(1): 105-109.

Hoffmann, S., C. Beierkuhnlein, R. Field, A. Provenzale \& A. Chiarucci 2018. Uniqueness of Protected Areas for Conservation Strategies in the European Union. Scientific Reports 8: 6445.

Iftime, A. 2005. Notes on the amphibians and reptiles in the region of Vidraru Dam Lake (Southern cline of Făgăraş Massif, Romania). Travaux du Muséum National d'Histoire Naturelle "Grigore Antipa» 48: $317-$ 326.

Iftime, A. \& O. Iftime 2006. Preliminary data on the herpetofauna of the Cozia Massif (Romania). 1. Reptiles. Travaux du Muséum National d'Histoire Naturelle «Grigore Antipa» 49: 331-340.

Iftime, A. \& O. Iftime 2007. Preliminary data on the herpetofauna of the Cozia Massif (Romania). 2. Amphibians. Travaux du Muséum National d'Histoire Naturelle «Grigore Antipa» 50: 259-271.

Iftime, A. \& O. Iftime 2008. Observations on the herpetofauna of the Giurgiu County, Romania. Travaux du Muséum National d'Histoire Naturelle «Grigore Antipa) 51: 209-218.

Iftime, A. \& O. Iftime 2010. Contributions to the knowledge of the herpetofauna of the eastern Jiu and upper Lotru drainage basins (Southern Carpathians, Romania). Travaux du Muséum National d'Histoire Naturelle «Grigore Antipa» 53: 273-286.

Iftime, A. \& O. Iftime 2011. Note on the herpetofauna of the Vâlcan Mountains and their foothills (Southern Carpathians, Romania). Travaux du Muséum National d'Histoire Naturelle «Grigore Antipa» 54(2): 533521.

Iftime, A. \& O. Iftime 2013. Observations on the herpetofauna of the Buila-Vânturarița Massif (Southern Carpathians, Romania). Travaux du Muséum National d'Histoire Naturelle «Grigore Antipa» 56(1): 93-101.

Iftime, A. \& O. Iftime 2014. Note on the amphibians and reptiles on the „Nordul Gorjului de Est” site of community interest and adjacent areas (Southern Carpathians, Romania). North-Western Journal of Zoology 10 (Supplement 1): S44-S50.

Iftime, A. \& O. Iftime 2015. Contributions to the Knowledge on the Amphibians and Reptiles of Teleorman County (Southern Romania). Travaux $d u$ Muséum National d'Histoire Naturelle «Grigore Antipa» 58(1-2): 63-71.

Iftime, A. \& O. Iftime 2017a. Data on the Populations of Bombina variegata (Amphibia: Anura: Bombinatoridae) from Cozia National Park and its Surrounding Areas (Vâlcea County, Romania). Travaux du Muséum National d'Histoire Naturelle «Grigore Antipa», 60(1): 389-399.
Iftime, A. \& O. Iftime 2017b. Contributions to the Knowledge on the Amphibians and Reptiles of Ialomiţa County (South-Eastern Romania). Travaux du Muséum National d'Histoire Naturelle «Grigore Antipa» 60(2): 505-516.

Iftime. A. \& O. Iftime 2019. New herpetological records from Cozia National Park and its surrounding areas (Vâlcea County, Romania). Travaux du Muséum National d'Histoire Naturelle «Grigore Antipa» 62(2): 221-233.

Iojă, C.I., M. Pătroescu, L. Rozylowicz, V.D. Popescu, M. Vergheleţ, M.I. Zotta \& M. Felciuc 2010. The efficacy of Romania's protected areas network in conserving biodiversity. Biological Conservation 143: $2468-$ 2476.

Kass, C., N.A. Kass, M.A. Velasco, M.D. Juri, J.D. Williams \& F.P. Kacoliris 2018. Inventory of the herpetofauna of Talampaya National Park, a World Heritage Site in Argentina. Neotropical Biology and Conservation 13(3): 202-211.

Krecsák, L., T. Sike \& T. Sos 2004. Distribution of the herpetofauna in the Lotrioara River basin, Sibiu District, Romania. Travaux du Muséum National d'Histoire Naturelle «Grigore Antipa» 47: 285-295.

Lamb, T., R.W. Gaul Jr, M.L. Tripp, J.M. Horton \& B.W. Grant 1998. A Herpetofaunal Inventory of the lower Roanoke River Floodplain. The Journal of the Elisha Mitchell Scientific Society 114(2): 43-55.

Leyte-Manrique, A., C. Berriozabal-Islas, V. MataSilva \& J.P. Morales-Castorena 2018. Herpetofaunal diversity in Área Natural Protegida Las Musas, Guanajuato, Mexico. Mesoamerican Herpetology 5(1): 122-136.

Niculae, M.I., S. Avram, G.O. Vânău \& M. Pătroescu 2017. Effectiveness of Natura 2000 network in Romanian Alpine Biogeographical Region: an assessment based on forest landscape connectivity. Annales of Forest Research 60(1): 19-32.

Ovreiu, A.B., I.A. Bărsoianu, L. Comănescu \& A. Nedelea 2018. Assessing the accessibility of relief for tourism activities. Case study - Cozia Massif (Southern Carpathians, Romania). GeoJournal of Tourism and Geosites 22(2): 509-523.

Ovreiu, A.B., I.A. Bărsoianu, L. Comănescu \& A. Nedelea 2019. Capitalizing of the geotourism potential and its impact on relief. Case study - Cozia Massif, Romania). GeoJournal of Tourism and Geosites 24(1): 212-236.

Ploaie, G. 2004. Parcul Naţional Coz̧ia. Editura Almarom, Râmnicu Vâlcea. [In Romanian].

Ploaie, G. \& D. Turnock 1999. Conservation and rural change in Valcea County. GeoJournal 46: 289-303.

Ploaie, G. \& D. Turnock 2001. Public perception of environment in the mountains of Vâlcea County. GeoJournal 54: 683-701.

Rădoane, M. \& N. Rădoane 2005. Dams, sediment sources and reservoirs silting in Romania. Geomorphology 71: 112-125.

Rozylowicz, L., A. Nita, S. Manolache, V.D. Popescu \& T. Hartel 2019. Navigating protected areas net- 
works for improving diffusion of conservation practices. Journal of Environmental Management 230: 413-421.

Russo, V.G., L.F. Russo, L. Coppari \& T. Notomista 2018. First record of Bombina variegata (Linnaeus, 1758) in a cave environment. Herpetology Notes 11: 967-969.

Schrödl, M. 2019. A scientist's warning: Stop neglecting biodiversity in climate change! Spixiana 42(1): $1-5$.

Sillero, N., J. Campos, A. Bonardi, C. Corti, R. Creemers, P.-A. Crochet, J. Crnobrnja Isailović, M. Denoël, G.F. Ficetola, J. Gonçalves, S. Kuamin, P. Lymberakis, P. de Pous, A. Rodríguez, R. Sindaco, J. Speybroeck, B. Toxopeus, D.R. Vieites \& M. Vences 2014. Updated distribution and biogeography of amphibians and reptiles of Europe. Amphibia-Reptilia 35: 1-31.

Slavchev, M.L., G.S. Popgeorgiev \& N.D. Tzankov 2019. Species Diversity of Amphibians and Reptiles in Relation to Habitat Diversity at a Natura 2000 Area in NW Bulgaria. Acta Zoologica Bulgarica 71(3): 377-384.

Stoenescu, Ş.M., A. Şchiop, I. Dica, E. Popescu, E. Patrichi \& E. Țepeş 1966. Atlasul climatologic al R. S. R., Bucuresti. [In Romanian]

Strugariu, A., S.R. Zamfirescu, A. Nicoară, I. Gherghel, I. Sas, C.M. Puşcaşu \& T. Bugeac 2008. Preliminary data regarding the distribution and status of the herpetofauna in Iaşi County (Romania). North-Western Journal of Zoology 4 (Supplement 1): S1-S23.

Sucea, F.-N. 2019. The Second Record of a Rare Lizard Species, Darevskia praticola (Eversmann, 1834), in the Jiu Gorge National Park, Romania. Ecologia Balkanica 11(1): 239-241.

Tomović, L., R. Ajtić, K. Ljubisavljević, A. Urošević, D. Jović, I. Krizmanić, N. Labus, S. Đorđević, M. Kalezić, T. Vukov \& G. Džukić 2014. Reptiles in Serbia - Distribution and Diversity Patterns. Bulletin of the Natural History Museum 7: 129-158.

Török, Z., O. Ghira, I. Sas \& S. Zamfirescu 2013. Ghid sintetic de monitorizare a speciilor comunitare de reptile si amfibieni din România. Editura Centrul de Informare Tehnologică Delta Dunării, Tulcea. [In Romanian].

Tuberville, T.D., J.D. Willson, M.E. Dorcas \& J. Whitfield Gibbons 2005. Herpetofaunal Species Richness of Southeastern National Parks. Southeastern Naturalist 4(3): 537-569.

Tufescu, V. 1986. Harta R. S. România. Editura Didactică şi Pedagogică, Bucureşti. [In Romanian].

Turnock, D. 2005. Romania's Railway Development 1950-1989: Changing Priorities for Socialist Construction. Geographica Pannonica 9: 32-43.

Turnock, D. 2006. The Romanian Carpathians under communism: the changing significance of a mountain region. Review of Historical Geography and Toponomastics 1(2): 157-206.

Velekei, B., F. Lakatos, S.-D. Covaciu-Marcov, I. Sas-Kovács \& M. Puky 2015. New Zootoca vivipara (Lichtenstein, 1823) haplogroup in the Carpathians. North-Western Journal of Zoology 11(2): 363-365.
Zamfirescu, S..R., A. Strugariu, P.C. Dincă \& I. Gherghel 2016. An updated distribution of the herpetofauna from the Natura 2000 Site Rarău-Giumalău (ROSCI0212), Romania. Memoirs of the Scientific Sections of the Romanian Academy 39: 16-35.

***** O.U.G. nr. 57 / 2007 privind regimul ariilor naturale protejate, conservarea habitatelor naturale, a florei şi faunei sălbatice. [In Romanian, Romanian law].

\section{Authors}

Severus-Daniel Covaciu-Marcov' - corresponding author

is a herpetologist and associate professor at the University of Oradea, Faculty of Informatics and Sciences, Department of Biology. His work focuses on biogeography, faunistics, the ecology of herpetofauna, and some invertebrate groups. E-mail: severcovaciu1@gmail.com

\section{Paula-Vanda Popovici ${ }^{1}$}

is an MS student at the University of Oradea, Faculty of Informatics and Sciences, Department of Biology, with an interest in the negative effects of human activity on wildlife.

\section{Alfred-Ştefan Cicort-Lucaciu'}

is a senior lecturer at the University of Oradea, Faculty of Informatics and Sciences, Department of Biology. He studies various aspects of conservation biology, faunistics and the ecology of newts especially, but also other animal groups.

\section{István Sas-Kovács}

is a senior lecturer at the University of Oradea, Faculty of Informatics and Sciences, Department of Biology, studying herpetology. His main focus is on amphibians, especially their ecology and biology.

\section{Diana Cupşa}

is a professor at the University of Oradea, Faculty of Informatics and Sciences, Department of Biology. Her main research domain is freshwater ecology, with a special focus on functional and conservation aspects.

\section{Sára Ferenţi ${ }^{1}$}

is an assistant at the University of Oradea, Faculty of Informatics and Sciences, Department of Biology, whose main research interests are in the ecology, biology and biogeography of terrestrial isopods and herpetofauna.

${ }^{1}$ University of Oradea, Faculty of Informatics and Sciences, Department of Biology; 1, Universității, Oradea 410087, Romania. 